\title{
Developmental State of Ethiopia: Reflections on the Benefits Obtained and the Costs Incurred
}

\author{
Endalcachew Bayeh*
}

\begin{abstract}
This research examines the progress achieved and the costs incurred as a result of the application of a developmental state model in Ethiopia. To this end, the researcher relied on secondary sources. Based on a thorough analysis of relevant sources, the following findings are obtained. Even though the developmental state has brought an observable level of economic growth, it has also caused several detrimental effects in other spheres: eroding the value of pluralism; endangering human rights; entrenching a single-party authoritarian rule; leading to rampant corruption; intensifying arbitrary intervention in the life of citizens. In implementing the model, the focus was on economic growth while the political aspect of it was sidelined. As a result, the researcher suggests that economic growth and political transformation (democratization) should be valued equally and pursued side-by-side, not in tandem.
\end{abstract}

Keywords: developmental state, authoritarian rule, Ethiopia, economic growth

DOI: https://dx.doi.org/10.4314/ejossah.v14i2.3

*Assistant professor, Department of Political Science and International Studies, Faculty of Social Sciences, Bahir Dar University, Email: endbayeh@gmail.com, Tel: +251921597152, P.O. box 79/ Bahir Dar

This work is licensed to the publisher under the Creative Commons Attribution-NonCommercialNoDerivs License. 


\section{The Notion of Developmental State}

The concept developmental state has no precise definition; it has been subject to an ongoing debate by authorities in the area. Notwithstanding this, the literature in the area has leaned more towards associating the term with the proactive role of a state in the economic development. It is conceived as a state which strives to achieve economic development by creating and regulating the economic and political relationships that can support a sustained industrialization (Chang, 2009). For Chalmers Johnson, developmental state is a state whose foremost and singleminded priority is economic development, defined in terms of growth, productivity, and competitiveness (Onis, 1991). It is still described as "a state that is and seeks to be a strong player in the economy of a nation with a view to enhancing economic development" (Sehen and Tsegaye, 2012, p. 7). Hence, the concept is closely associated with the rapid advancement of industrialization and socio-economic transformation through a strong government involvement in the economy. It is claimed that the developmental state has been initially practiced in the $19^{\text {th }}$ century, notably, Bismarck's Prussia and Meiji's Japan (Bolesta, 2007; Johnson, 1982; Chang, 2009). However, the most remarkable experience of it with a successful socioeconomic transformation was recorded in the East Asian states between the 1960s and 1980s (Fritz and Menocal, 2007). The application of such a model enabled them to miraculously advance their economy and escape from the perils of poverty (Kim, 2009; Boyd and Ngo, 2005). As a result of this fact, scholars on the subject use the developmental state theory mainly to explain such a rapid industrialization and economic growth in the East Asian states, which are also referred as the Asian Tigers (Bolesta, 2007; United Nations, 2007; Boyd and Ngo, 2005).

Ideologically, the developmental state is neither a capitalist nor a socialist system. It, rather, lies in between a free market capitalist economic system and a centrally-planned command economic system (Bolesta, 2007; Boyd and Ngo, 2005). It borrows certain features from these diametrically opposite politicoeconomic perspectives. While retaining the capitalist economic environment, the developmental state ideology encourages state intervention in the economy. This is true because, as Johnson (1982) notes, a developmental state sets a substantive social and economic goals. It is even understood as "an emphatic state, a hard state, relatively autonomous/independent, with a decidedly interventionist bent on seeking not only to regulate, guide, and shape, but also to monitor and control, the economy" (Sehen and Tsegaye, 2012, p. 19). However, this does not mean the replacement of the market with a socialist system of planning and control (Heywood, 2013). Developmental state is not, again, identical with a social 
democracy that is also a blend of capitalist and socialist systems. This is because in the developmental state intervention is required to bring economic progress while in the social democracy intervention is justified by ensuring fairness, equality, social justice, and support to the underdogs (Sehen and Tsegaye, 2012, p. 19). A developmental state is, thus, an interventionist state which is devoted to play a central role in bringing a fast economic development.

\section{Some Underlying Features of a Developmental State}

As can be deduced from the literature on the subject, a developmental state is characterized by, but not limited to, the following basic features. Firstly, the overriding objective of a developmental state is achieving a fast socioeconomic development via the process of industrialization (Bolesta, 2007). In so doing, a shift from import-substituting industrialization to export-oriented industrialization is necessary (Kim, 2009). East Asian states achieved a rapid economic development since technocratic bureaucrats have made economic development their top priority and long term goal (Boyd and Ngo, 2005).

Secondly, developmental state needs a competent meritocratic autonomous bureaucracy. In a developmental state, bureaucrats are powerful professionals who are protected from the influence of elected politicians (Sehen and Tsegaye, 2012; Bolesta, 2007; Asayehgn, 2012). They facilitate the socioeconomic transformation of a state by enjoying a high degree of political autonomy (Haggard, 2018; Bolesta, 2007; Boyd and Ngo, 2005). Relating to this, it is stated that the politicians "reign" while the bureaucrats "rule" (Haggard, 2018; Onis, 1991). This indicates the real power of bureaucrats in the development endeavor of a state. This meritocratic recruitment of such autonomous, capable bureaucrats takes the center stage in the East Asian states' miraculous, skyrocketing economic performance (Edigheji, 2010).

Thirdly, a developmental state is an interventionist state in nature. The state actively involves in the economy by regulating, guiding and controlling it. Its intervention is single-mindedly aimed at promoting industrial growth and economic development (Heywood, 2013).

Fourthly, it has a capitalist economic environment, as private sectors are partners in the development of a state (Bolesta, 2007; Onis, 1991). In other words, there is a public-private partnership. However, the partnership is not open to all private sectors; rather, it is for selected strong enterprises that enjoy government subsidies. Besides, such a public-private cooperation/partnership doesn't result from voluntary compliance by the private business elites; rather, it is due to the coercive influence of bureaucrats (Onis, 1991). 
This model is now spreading, beyond East Asia, across various countries of the world. Many countries are rushing to adopt the East Asian model of development, albeit in some countries with necessary alterations. Ethiopia, which is what this paper mainly grapples with, is no exception in this move. Concerns regarding whether a developmental state model is applicable in Ethiopia have taken center stage in the recent literature (i.e. Ayenachew, 2014; Sehen and Tsegaye, 2012; Mesgna, 2015).

\section{Methodological Consideration}

This article adds to the existing discourse on the subject by examining the actual and potential gains and costs (a relatively less discussed aspect) of the adoption of a developmental state model in Ethiopia. This motive has emanated from the writer's thesis that the Ethiopian government has taken economic growth as a metric of governance and hence applied (and potentially will continue to apply) the developmental state model at the costs of some basic democratic precepts to ensure its long-lasting survival in power. Accordingly, the researcher tries to achieve the following basic research objectives.

- To shed light on the patterns of change in the ideological orientations of Ethiopia across the last successive three regimes

- To reveal the actual and potential positive effects of a developmental state model in Ethiopia

- To examine the actual and potential adverse effects of a developmental state model in Ethiopia

This study employed a qualitative approach. Qualitative research attempts to interpret phenomena in terms of the meanings people attach to them. In other words, qualitative research is, basically, interpretive in that it involves analyzing data and finally making interpretation or drawing conclusions about the data analyzed (Creswell, 2003). Accordingly, secondary data that were collected through a thorough reading of books, journal articles, reports, and credible internet sources are qualitatively interpreted and analyzed.

\section{Patterns of Change in the Ideological Orientations of Ethiopia}

Historically Ethiopia has experienced various forms of politico-economic orientations across different regimes. The country underwent an age-old "feudal" system until the collapse of the imperial (Haile Sellasie) regime by popular upheaval in 1974. This long history of "feudalism" was characterized by a 
traditional social structure where the critical means of production was land; hence agriculture was the engine of development throughout the imperial period. This quasi-feudal system defined the social/production relations of the two fundamental social classes, namely the peasantry and the landlord (Addis Hiwet, 1975; Alemayehu, 2007). Accordingly, the social relation was exploitative in that peasants were reduced to tenants and subordinated to the landowners. This was very much apparent especially in the southern part of the country (Markakis and Nega, 1986). The political system during the Imperial period was also highly centralized under a despotic monarchy, which used to allocate land to those who kept their allegiance and support to the government. And, there was no room for alternative political forces to organize and make heard the voices of both rural and urban people. Eventually, the politico-economic suffering led to the above mentioned popular revolt (involving peasants, drivers, teachers, soldiers, students) in 1974 that ended up with toppling Emperor Haile Sellasie and terminating the age-old monarchical rule in Ethiopia once and for all.

Following this historic event, the Military regime (Derg) acceded to the ruling power with a completely different ideology, socialism, or command economic system, as Ethiopia joined the Eastern bloc. This happened by eradicating the feudal system and making land a public property. However, the period of this militaristic rule has been blamed to be "lost decades" because of economic stagnation (Arkebe, 2018). Between 1974/75 and 1989/90, the average GDP growth was decelerated to $2.3 \%$ from $4 \%$ between 1960 and 1974 (Alemayehu, 2007). This was attributable to the economy's dependence on agriculture, which is vulnerable to the vagaries of nature. Also, the compulsion of farmers to provide military service coupled with the institution of centralized planning and the nationalization of land, among others, made agriculture stagnant and unable to support the industry. Moreover, given the militaristic nature of the rule and the prevailing recurrent political turmoil, the precedence was given to the defense industry and hence capital investment was geared towards defense needs, which were mostly met by the Soviet Union and its allies (Arkebe, 2018). Eventually, the regime was deposed mainly because of the political setbacks.

After experiencing a centrally-planned command economic system until the fall of the Derg regime in 1991, the current government, again, came up with a western liberal ideology (Tsehai, 2009; Muller, 2015). At the time, it was not convenient to follow some other types of politico-economic model as the prevailing world-wide dominant ideology was liberal capitalism following the conclusion of the Cold-War with the triumphant success of the Western bloc led by the US. This was the time that marked, for Francis Fukuyama, the end of history of 
mankind's ideological evolution (Fukuyama, 1989). Most importantly, it was the US that contributed a lot in bringing the Ethiopian People's Revolutionary Democratic Front (EPRDF) into power. Thus, to show its allegiance and thereby enjoy US's and some other western states' blessings in the course of consolidating its power, jumping on the bandwagon and advocating the liberal ideology was the choice at hand. One can maintain the fact that the country subscribed to the western liberal ideology has helped the regime in consolidating its power. However, facts on the ground show that such an adherence to western ideology brought neither a real western type of liberal electoral democracy nor economic development. In fact, the regime was overlapping the model with another politicoeconomic world view, i.e. revolutionary democracy, and its liberal democracy rhetoric was not consistent with the actual practices. Hence, the government's official adoption of the model was just a token move in response to external pressures.

After advocating a free market economic system for about ten years, the government officially declared its shift to the developmental state model, without still a clear break from its revolutionary democracy adherence, believing that the free market economic system cannot function in Ethiopia's condition without a well thought out state intervention (Muller, 2015). The conviction came on account of the fact that the country's economy was very small and the factors of production were highly constrained and thus impossible to compete in the global market unless the state takes the guiding role on development (De Waal, 2018). Consequently, the state has been empowered to guide the country's entire economy, not to invest at micro-scale. This change came along with the rise of Asian countries with an alternative economic model, thereby diminishing the country's exclusive dependence on the West. The formal introduction of the idea of developmental state in Ethiopia is, therefore, a recent phenomenon. Concerns regarding whether the developmental state model is applicable in Ethiopia have recent national discourses by researchers, politicians, and been the focus of the academia. The following sections discuss the progress witnessed and the detrimental effects encountered (and possibly will continue to encounter) because of the model adopted and the way it is implemented.

\section{Highlighting the Economic Progress}

It is imperative to acknowledge the progress witnessed in the country following the adoption of the developmental state model. This is true, especially, with regard to the country's economic performance. The adoption of this model almost coincided with the formal launch of Sustainable Development and Poverty Reduction 
Program (SDPRP) in 2003, focusing on agriculture, education, and infrastructure development (UNDP, 2017). The program elevated the GDP from $2.3 \%$ to 5.9\%, though it could not take people out of a grinding poverty. Building on the positive achievements of the program in 2005, Plan for Accelerated and Sustained Development to End Poverty (PASDEP) was launched emphasizing on urban development, which was overlooked in the previous program (UNDP, 2017). With this initiative, the country managed to achieve a high economic growth $(11 \%)$ and reduced the poverty level.

Most importantly, the developmental state orientation has been substantiated with the Growth and Transformation Plan I and II. With the conviction that the increasing economic performance attained by the aforementioned programs could not be sustained without focusing on the manufacturing sector, the government introduced the Growth and Transformation Plan I in 2010/11. In the endeavor to realize this objective, the Plan authorizes the state to take the key leadership role (Planel and Bridonneau, 2015). Currently, Plan I has phased out and replaced by Plan II. The progresses achieved following such a move are discernible, especially when one looks at the expansion of industries from time to time. The country is working on a new line of industrial development. One can mention the very recent examples: the Hawassa Industrial Park (centered on textile and garment products) and Bole Lemi I Industrial Park (industrial hub for export- oriented manufacturers) which have recently become operational, while having many other ongoing projects. ${ }^{1}$ These industries are promising in terms of enhancing the country's economy. This is not, however, to discard some others' fear that the benefits of these mega projects would come and trickle-down to the poor at some distant future and thereby calling for a small-scale citizen-friendly engagements (Ayele, 2018). The concern is legitimate because the benefits of these grand projects may not necessarily be enjoyed anytime soon.

The aforesaid successive development initiatives, forming part of the broader developmental state model, produced a persistently increasing economic development in the country (Clapham, 2017; Fesseha and Abtewold, 2017). The record of the growth rate varies across different sources. For instance, as noted in Clapham (2017), by the year 2015, the country's GDP growth rate was $9.6 \%$, making it the highest in Africa and second highest in the world. Based on the World Bank's report, Ethiopia scored annual growth rates of $10.4 \%$ in $2015,7.6 \%$

\footnotetext{
${ }^{1}$ Please visit this link http://www.investethiopia.gov.et/investment-opportunities/strategicsectors/industry-zone-development to see more on the projected additional industrial parks in several parts of the country, namely Mekelle, Dire Dawa, Kombolcha and Adama.
} 
Endalcachew Bayeh

in 2016, and $10.2 \%$ in 2017 (WB, 2018a). It also affirms that the country achieved a remarkable economic growth averaging $10.3 \%$ a year from 2006/07 to 2016/17, compared to a regional average of 5.4\% (WB, 2018b). For the UNDP also the GDP growth has shot up from $8.0 \%$ in $2015 / 16$ (due to drought) to $10.9 \%$ in 2016/17 (UNDP, 2018). Industry, especially the construction sub-sector, was the major contributor to growth in $2016 / 17$ by taking over the services sector (ibid), probably indicating the emphasis given to the manufacturing sector in the GTP I\&II. Despite the minor numeric variations, the progress manifested in the country has been acknowledged and testified by all authorities without reservation. This incredible achievement ranked Ethiopia among the world's fastest-growing economies in 2018 (WB, 2018c). Along the same line, the share of the population living below the national poverty line diminished from $30 \%$ in 2011 to $24 \%$ in 2016 (WB, 2018b); while based on the international poverty line, poverty dropped from $27 \%$ in 2016 to $24 \%$ in 2018 (WB, 2018c). It is therefore undeniable that the developmental state orientation has brought impressive changes in respect of economic growth and industrialization.

To stimulate and sustain the industrialization process in particular and economic transformation in general, the government has provided due attention to infrastructural development by allocating a significant share of its national budget. This is observable from the government's dedication to expand roads, railways, air transport, electrification, telecommunication, among others. In this respect, significant progress has been achieved, which is instrumental in the effort to make the country appealing for investment.

The above noted promising economic growth coexists, however, with considerable downsides. There is a huge discrepancy between the rich and the poor. It is still possible to see people leading luxurious life and others suffering from a poverty quagmire. The economic growth could not significantly ameliorate this difference. Again, the health of the above indicated economic growth is questionable as there is a strong critique over its uneven distribution among various groups in the society (Melisew and Cochrane, 2018). For instance, according to Oxford Poverty and Human Development Initiative (OPHI) (2017), the percentage of the population living in severe poverty in Somali Region (81.9\%) is much higher than Harari (36.6\%) and Dire Dawa (38.5\%). Similarly, the level of poverty reduction is not equal across urban and rural areas; the percentage of the rural population living in severe poverty is much higher $(82.1 \%)$ than the urban population (21.0\%), almost a quadruple. World Bank (2018c) also supports this assessment, arguing that poverty reduction is stronger in the urban areas while slower in the rural areas. This is attributable to the government's favor to major 
cities over rural areas (IRIS, 2017). Moreover, corruption and illicit financial flows are what the government has strongly been blamed for.

\section{Some Detrimental Effects}

Notwithstanding the above marked economic progress, the developmental state model has not been flawlessly applied. Though the government says it is pursuing a democratic developmental state model, so far, it has worked mainly on the economic aspect of it and political transformation has been sidelined. It is rather true that the constantly achieved observable level of economic growth has served as a metric of governance, justifying all political malpractices and legitimizing the ever-increasing authoritarian tendency of the government (De Waal, 2018; Gebremariam, 2018; Fantini, 2013). It must be noted that it is not just the developmental state model per se that created the problem, but also the appropriation of the system's natural tendency to authoritarianism by leaders as a good opportunity to sustain their power and deepen their control. There are democratic developmental states; what counts is the presence of a committed and civic-minded leadership, which actually is missing in Ethiopia. Hence, democratic form of governance has remained a mere aspiration of the citizens. Simply put, Ethiopia is a democratic developmental state in name and an authoritarian developmental state in reality. In what follows, I will discuss the major aftermaths.

\section{Eroding the Value of Pluralism}

For a better realization of developmental state theory, a state needs to insulate itself from the demands of diverse social classes (Minns, 2001; Kim, 2009; Fritz and Menocal, 2007; Sehen and Tsegaye, 2012; Minns, 2006; Boyd and Ngo, 2005; Mkandawire, 2001). This assertion is based on the conviction that diverse local demands can detract the capacity of a state from achieving a better overall economic performance (Fritz and Menocal, 2007; Minns, 2006; United Nations, 2007). Concurring with this, Onis (1991, p. 119) contends that a developmental state model is "inconsistent with the vision of a pluralistic form of democracy, in which a multitude of small-scale interest groups enjoy broadly equal and unrestricted access to the state." This is why some maintain that a developmental state neglects special interest claimants who may divert it from its main developmental priority (Onis, 1991, p. 119). Though it is not entirely impossible for a developmental state to consider diverse local interests, it is quite challenging and needs a determined, robust leadership.

Ethiopia is the home of diverse ethnic, religious, and cultural groups. The division along these lines with different, in some cases conflicting, interests can be 
a potential bottleneck in implementing the developmental state model as it hampers the consensus required for the model. However, it is also equally difficult to disregard the interests of these diverse groups. It seems to reconcile this contradiction that the state intentionally added a prefix democratic to the developmental state model (Muller, 2015). However, there are still disatisfactions by various groups regarding the division and sharing of power, resources, and social opportunities (Sehen and Tsegaye (2012). The resentments intensified as the government operates based on the policies and agendas set by the ruling-party at the center, without securing the consent and incorporating the interest of the diverse local community. Local knowledge, peculiarities, inputs and concerns have not been given due attention, while the very diversity of the people, ipso facto, necessitates the involvement of the people in the country's affairs. The single vanguard political party acts for the people in an I know for you logic. This is against the cardinal principle of a pluralistic democracy, which is popular participation. That is why, based on the Freedom House's assessment, Ethiopia has ranked worst for scoring 0 out of 16 in 'political pluralism and participation', owing to the exclusion of the public from any genuine and autonomous political participation (Freedom House, 2018). The resultant political demonstrations erupted in various parts of the country were all quashed by the law enforcement agents of the government. It is therefore evident that the government has given a deaf ear to the peoples' voices, ideas, and opinions considering them as a negative energy dragging the government back from its way to ensure economic development.

This happened, partly, due to the mingling of developmental state with the governments' philosophy of democratic centralism (that was borrowed from Lenin who used it to organize a tightly disciplined and centrally organized vanguard party) (Heywood, 2010) and revolutionary democracy that naturally allows for the political stage to be occupied by a few politicians relegating the public at large (Lefort, 2012). On this account, as Fantini (2013, p. 1) writes "development policies, targets and programs are designed at the centre, authorizing regional and local authorities little room for maneuver, in a centralistic and top-down logic." Despite the formal decentralized federal structure, there has been "little recognition for local knowledge or the autonomous aspirations of groups and individuals" (Fantini, 2013, p. 6) thereby compromising the value of pluralism in the country. Differently put, a small circle of individuals in the ruling-party at the center sets and decides everything in a one size fits all attitude for the heterogeneous Ethiopian society. It would therefore be naïve to expect the flourishing of 
pluralism with a dominant ruling-party committed to democratic centralism (Gebremariam, 2018).

The author's conviction is, if the government, under the new leadership, continues to insulate itself from popular voices, local claims, and feelings of alienation just to achieve national developmental goals, the existing grievances manifested here and there can be intensified and further lead to severe conflicts and inter-group resentments in the country. This, in turn, would erode the chance for peace and development and renders the value of pluralism preached by the government meaningless. Therefore, the natural inclination of the involvement of the developmental state deep into economic performance, together with the weak commitment of the government of Ethiopia to entertain local claims, can worsen the existing grievances of the deeply divided society, whatever camouflaging (democratic) term the government may use. The destructive conflicts would, in turn, negatively affect the country's economic growth. Hence, exerting the best possible effort to have consensus-oriented governance is mandatory, given the deeply divided society the country has.

\section{Endangering Human Rights}

It is true that a developmental state theory requires a strong interventionist state. However, this does not mean that a developmental state theory is compatible only with authoritarian states as one can adduce the cases of Brazil, India, South Africa, Mauritius and Botswana, which run democratization and developmental programmes simultaneously (Fritz and Menocal, 2007). However, by virtue of its primary focus on economic development, one can note the likelihood of repression of certain rights and freedoms. In this respect, Bolesta (2007, p. 107) contends that "it seems justifiable to claim that a developmental state would be difficult to sustain in a fully democratic system in which people enjoy extensive rights." It follows that a developmental state can be practiced at the cost of compromising the full enjoyment of human rights.

Ethiopia has had an abysmal human rights violation records across successive regimes, in spite of the country's subscription to various national, regional and international human rights instruments (for details, see Endalcachew, 2014). The current regime -EPRDF- is characterized by massive violations of human rights, especially civil and political rights. The regime's adherence to a developmental state model has served as a cover for further violations of the rights of citizens, as the model is preoccupied with economic growth. In giving priority for economic development, Meles Zenawi, the late prime minister of Ethiopia and the mastermind behind the introduction of this model to Ethiopia, plainly asserted 
Endalcachew Bayeh

that "development and a strong state were prerequisites for human rights, and Ethiopia needed to establish these first" (De Waal, 2012, p. 155). He boldly and loudly stated that "We must have growth, growth, growth......we can't have democracy with an empty belly" (De Waal, 2018, p. 5). One can infer from this argument that it is possible to put aside democracy in general and human rights in particular until a certain degree of economic development and state strength is achieved. In the course of questioning the genuine applicability of the model in the country, there is even a strong argument that the very reason of the country to turn its face to Eastern governments is because of their indifference for human rights and democracy (Muller, 2015).

The bottom-line is economic development has been used, and will potentially continue to serve, as a legitimizing force for the violation of the rights of citizens. This issue would be much worrisome if one thinks of the waning of the pressure of the international community over domestic human rights records of states overtime (Melisew and Cochrane, 2018). The researcher maintains that economic growth and human rights should be pursued simultaneously, not in tandem as articulated by Meles; the freedoms of citizens must not be suppressed under the cover of economic growth. After all, the growth achieved through domineering citizens would not be sustainable as it inevitably raises grievances and instabilities. The recent political unrest permeated the country and the resultant destructions and losses caused are best evidences corroborating this argument. Hence, human rights are not luxury goods to be preceded by economic growth; they are rather equally intrinsically necessary.

\section{Entrenching a Single-Party Authoritarian Rule}

Athough the developmental state model is adopted both in democratic and undemocratic states, considerable researchers contend its difficulty in a democratic political environment (Haggard, 2018; Bolesta, 2007; Fritz and Menocal, 2007; Sehen and Tsegaye, 2012). This claim is drawn from the very nature of democracy to decentralize power and to make the state less autonomous and less insulated from societal demands (Fritz and Menocal, 2007), which is inconsistent with the requisites of a developmental state. Developmental states provide priority to economic development over political reform undermining the democratization process. Governments oriented towards the developmentalist ideology establish a strong and stable government that suppresses anything which goes against their developmental goals, as legitimacy is drawn from developmental achievements not from the consent of the people (Bolesta, 2007; United Nations, 2007). It is this fact which compelled scholars on the subject to affirm that there is a high tendency of a 
developmental state becoming authoritarian, and to fear the replication of the East Asian model in other regions (Sehen and Tsegaye, 2012).

There is a fragile democracy in Ethiopia underscoring the claim that developmental state has a tendency of becoming authoritarian. Its political governance has been characterized by a highly centralized single-party rule (EPRDF) (Clapham, 2006). There are authorities who argue that the raison d'être of the developmental state in Ethiopia is to ensure the continued authoritarian single-party dominance (Ayenachew, 2014). This argument makes sense if one closely examines the conviction of Meles about the importance, inter alia, of maintaining policy continuity for a sufficiently long time for a developmental state to succeed (De Waal, 2012). This idea goes against the very nature of electoral democracy which is prone to frequent government changes and perhaps policy discontinuity (Tsehai, 2009). On top of this, Meles went so far as to say "there is no reason to believe that democratization is a precondition of economic development", (Melisew and Cochrane, 2018: 8) by adducing economic developments under dictatorships in USSR and Germany (Fesseha and Abtewold, 2017). It is economy and economy that matters!

The practice on the ground has been in line with these ideas that the rulingparty has had an iron grip on political power. The political space and all state apparatuses have for long been controlled by EPRDF and the country has undergone a democratic deficit. The government further expanded its control and deepened its dictatorship, especially following the 2005 historic election by eliminating anything challenging it, i.e. the opposition parties, civil society organizations and the media, among others. The late prime minister had a pessimistic attitude towards all these agents of democratization arguing that they would 'easily become patronage mechanisms' in the Ethiopian context (Melisew and Cochrane, 2018) and as a result acted towards their complete elimination and thus ensured the ruling-party's political hegemony. The successive elections, as well as, multi-party system in the country are all façades, manipulated to consolidate the ruling-party's authoritarianism.

It is this context which forced some authorities to comment that Ethiopia is following an 'authoritarian developmental state' model (Thakur, 2009). Matfess (2015) labeled the Ethiopian system of governance as "developmental authoritarianism" controlling virtually every aspect of the society. In a nutshell, the people have suffered from a heavy-handed single-party authoritarian rule under the cover of ensuring the country's stability and policy continuity for an effective realization of a developmental state model. 


\section{Leading to Rampant Corruption}

The developmental state model is susceptible to corruption, though it is a possibility in other ideological models too. Unless the model is genuinely implemented, the state's intervention in and control of the economy can pave the way to misuse of state power and embezzle public assets. It is stressed that "in the process of enriching the nation, the state might prefer to enrich itself and not the people" (Bolesta, 2007, p. 111). The close relation between economic bureaucrats and business sectors also leads to collusion or monopoly as it is witnessed in a series of corruption scandals in Japan and South Korea (Kim, 2009).

It is plausible to make a remark that adopting and enforcing a developmental state model in an already corrupted bureaucratic system would be dangerous. It is common knowledge that African countries are notorious for their corrupt practices. This is affirmed by the United Nations (2007, p. 74) "African states are too corrupt and predatory, and ruled by rent-seeking or just plain kleptocratic officials who prioritize their private interests over those of the state, and use rents to fund patronage for their constituents". Ethiopia is no exception; corruption prevails in different sectors. It is the researcher's belief that the country's adherence to the developmental state model has intensified the prevailing problem by giving officials a better chance to exploit the core economic sectors. The practice on the ground also proves this conviction. One can mention the recently spotlighted gross scandals in Sugar Corporation, Grand Ethiopian Renaissance Dam, Ethiopian Shipping and Logistics Services Enterprise, Ethiopian Civil Aviation, and Yayu Fertilizer Factory (Fana TV, November 2018), among others, to understand how much core economic sectors have been embezzled by top government officials. The greedy officials have, using their interventionist role and better relation with business sectors, exploited the country's resources massively and deposited the money abroad (Wubalem, 2016) while the poor are suffering from a grinding poverty and the government is looking for aid and loans from abroad.

Corruption has therefore been deeply rooted in the Ethiopian political system and developed as an independent, strong system with a tough interest chain among officials at various levels of the government structure. On account of its strength and influence, corruption was labeled by the current Prime Minister, Abiy Ahmed, as 'the fifth government' during his speech on the national anti-corruption day.

Corruption creates not just unjustifiable income inequalities among citizens, but also causes conflicts and instabilities that, in turn, produce a breeding ground for intensified corruption. 


\section{Intensifying arbitrary intervention}

State intervention in the economy is a core feature of a developmental state model. However, the intervention should be made selectively in a way that facilitates the overall economic performance of a country. While this should have been the case, the reality in Ethiopia has shown an unlimited intervention of the state "to the extent of being market unfriendly" (Ayenachew, 2014). This arbitrary and unrestricted interference in the economy has brought several detrimental effects like inflation and shortage of access to some basic commodities. This is against the very principle of developmental state model where the government intervenes in a capitalist economic environment (Bolesta, 2007).

The most terrible effect of state intervention comes into the picture when one considers the issue of land ownership in Ethiopia. Ethiopians have a strong sentiment to land, which has for long been the crucial source of livelihood. The 1995 FDRE constitution explicitly confers the ownership of urban and rural land to the state and its people (Art.40). And yet, it authorizes the state to displace citizens from their settled life when it is for the purpose of "development" or "public interest" by providing a commensurate compensation (Art.44). By using this permissive legal framework, the interventionist state has carried out several development programs, sometimes by adversely affecting citizens and leading them to serious grievances. The government has displaced several families, sometimes by inappropriately and extensively interpreting public interest. In this respect, one can adduce the displacement in Gambella and other Southern parts of the country and the Integrated Master Plan (IMP) for enlarging the capital city into the Oromo region (Matfess, 2015). The displacement is much more intense in Addis Ababa; countless people have been displaced from the center to the suburb in the name of public interest. And, the problem is that both sides loose: neither the displaced families get enough compensation to resume their life at where they are dumped nor the government projects are fully materialized to serve public interests.

\section{Recent Changes: too Little too Early}

Very recently, following Abiy Ahmed's premiership, some positive changes have been observed. Within a short time, the government has created optimism on the part of the people. To mention some positive changes witnessed, the government is striving to liberalize the political space for various competing forces. Exiled opposition political parties were all invited to come back, and almost all are now operating domestically side-by-side with the ruling party, which was the only game in town. The opening up of the political horizon is also evidenced from the 
Endalcachew Bayeh

freedom that the media are enjoying. They are addressing several political issues including serving as a platform to challenge the government, which was not possible in the pre Abiy leaderships. Moreover, the government is revising the Charities and Societies proclamation that has for long keptout civil society organizations from political activities, especially in the post-2005 election.

The prime minister has also started to build the legitimacy of the government through reforming various institutional frameworks, including the security institutions. The government has made a good start in listening the voices and concerns of the people. The new prime minister began his office by conducting a public discussion in several parts of the country, which allowed the people to express their pressing issues.

In addition, the government is trying to serve justice by bringing transgressors to the courts of law. In view of this, some top government officials are brought before a court for their grave corruption scandals. This tells us that the new administration has started the anti-corruption struggle. Those engaged in massive human rights violation as well have started facing justice.

Despite the positive changes seen, the government is entangled with various challenges. One basic challenge is that the government lacks internal coherence as the parties constituting the coalition government have no common understanding of the ongoing reforms being made and future programs and visions of the government (Semir, 2018). Being dissatisfied by the reform, the TPLF is operating virtually independently in its constituency. As a way of undermining the actions being taken by the new leadership, it has shielded its former flagitious top officials who were involved in corruption and human rights violations from facing justice. This entails that the government is not exercising an effective control over the entire territories of the state. On top of that, the weakening of the coalition has undermined the state's monopoly on the use of force to ensure peace (Michael, 2018). To complicate the matter, some opposition factions that recently entered the country are also colliding with the government and igniting the upsurge of violence in different parts of the country. As a consequence, lawlessness, insecurity, and distrust have become very critical concerns unfathomably complicating the country's long-standing problems.

There are ambivalent feelings as to the country's possible transition to democracy. The situation is truly represented as, to use Solomon's words, "Ethiopia's spring of hope and winter of despair" (Solomon, 2018). Despite the reforms started, it is difficult to believe beyond any doubt that the changes brought so far by the new administration are likely to continue and bring the long-awaited genuine political change in the country. In this connection, there are even concerns 
that the new prime minister has been hanging on pressing issues for propaganda and media consumption without establishing new solid institutional setups on the ground. Besides, even some new changes have created new concerns on the part of some ethnic groups.

Moreover, there is a reasonable fear that the country's age-old authoritarian culture of governance may still have a lingering effect. Hence, the country is cross-roads; it is thus difficult to arrive at a conclusion based on the aforementioned progresses made by the government. The new changes witnessed are too little too early to be optimistic. On top of that it is unclear whether Abiy's rule will continue to implement the developmental state model or make a departure from it. For that matter, the prime minister did not say anything about the developmental state orientation of the country, being more concerned with the spiraling political turmoil in the country.

\section{Conclusion}

The developmental state model was introduced in Ethiopia by the incumbent government after a decade of rule based on the western liberal model. Following the rise of alternative politico-economic model in the East, the government resorted to the developmental state, believing that the western free market economic system cannot function in Ethiopia's condition without a selective state intervention. The developmental state model has brought an exponential economic growth testified by various researchers and international multilateral financial institutions. However, the government has used the increasing economic growth as a metric of governance and thus prioritized economic development and put off democracy to be achieved down the line. The natural inclination of the model to despotism, coupled with the inherent interest of the ruling-party to sustain its power and deepen its control, caused an improper application of the model and put the country with an ever-increasing authoritarianism. Very recently, some important changes are being made in the political realm following the appointment of a new prime minister, but the changes are too little too early to rely on to conclude that the government is properly applying the model and the country is entering into a genuine democratization process. 
Endalcachew Bayeh

\section{References}

Addis Hiwet. (1975). From autocracy to bourgeois dictatorship. Review of African Political Economy, 1, 1-94.

Alemayehu Geda. (2007). "The political economy of growth in Ethiopia" In Ndulu, B., O'Connell, S., Bates, R., Collier, P. and Soludo, C., (Eds.), The political economy of economic growth in Africa, 1960-2000. UK: Cambridge University Press.

Arkebe Oqubay. (2018). Industrial policy and late industrialization in Ethiopia (Working Paper Series $\mathrm{N}^{\circ}$ 303). Retrieved from https://www.afdb.org/fileadmin/uploads/afdb/Documents/Publications/WP S_No_303_Industrial_Policy_and_Late_Industrialization_in_Ethiopia_B. pdf

Asayehgn Desta. (2012). The continuing saga of globalism: Comparing Ethiopia's developmental state strategies to those of Malaysia. International Journal of Management Sciences and Business Research, 1(11), 87-103.

Ayele Gelan. (2018 October). What is happening to EPRDF's developmental state. Addis Standard. Retrieved from http://addisstandard.com/commentary-what-is-happening-to-eprdfsdevelopmental-state/

Ayenachew Aseffa. (2014). Indicia of the developmental state concept in the Ethiopian Higher Education (Master's thesis). Retrieved from: https://tampub.uta.fi/bitstream/handle/10024/95990/GRADU1408537281. pdf

Bolesta, A. (2007). China as a developmental state. Montenegrin Journal of Economics, 5, 105-111.

Boyd, R., \& Ngo, T. (2005). "Emancipating the political economy of Asia from the growth paradigm"' In Boyd, R. and Ngo, T., (Eds.), Asian States: Beyond the developmental perspective. New York: Routledge Curzon.

Chang, D. (2009). Capitalist Development in Korea: Labour, Capital and the Myth of the Developmental State. London: Routledge.

Clapham, C. (2006). Ethiopian development: The politics of emulation. Commonwealth \& Comparative Politics, 44(1), 108-118.

Clapham, C. (2017). The Ethiopian developmental state. Third World Quarterly, 39(6), 1151-1165.

Creswell, J. (2003). Research design: Qualitative, quantitative, and mixed methods approaches $\left(2^{\text {nd }}\right.$ ed.). Thousand Oaks: Sage Publications, Inc. 
De Waal, A. (2018) The future of Ethiopia: Developmental state or political marketplace? USA: World Peace Foundation. Retrieved from http://www.africanidea.org/The-future-of-ethiopia_development.pdf

De Waal, A. (2012). The theory and practice of Meles Zenawi. African Affairs, 112(446), 148-155.

Edigheji, O. (2010). "Constructing a democratic developmental state in South Africa: Potentials and challenges." In Edigheji, O., (Ed.), Constructing a democratic developmental state in South Africa: Potentials and challenges. South Africa: Human Sciences Research Council Press.

Endalcachew Bayeh. (2014). Incorporation of human rights into legal frameworks of the three successive regimes of Ethiopia and their treatment: A comparative analysis. European Journal of Humanities and Social Sciences, 32(1), 1736-1751.

Endalcachew Bayeh. (2018). Single-party dominance in Ethiopia: FPTP electoral system and parliamentary government system as contributing factors. RUDN Journal of Political Science, 20(4), 506-515.

Eyob Balcha. (2018). "The carrot and stick of Ethiopian 'Democratic Developmentalism': ideological, legal and policy frameworks" In Tapscott, C., Halvorsen, T. and Cruz-Del Rosario, T., (Eds.), The democratic developmental state: North-South perspectives. Colombia: Columbia University Press.

Fana TV. (2018). Metec corruption exposed "documentary". Retrieved from: https://www.youtube.com/watch? $\mathrm{v}=\mathrm{NRre} 1 \mathrm{adxyCU} \& \mathrm{t}=6 \mathrm{~s}$

Fantini, E. (2013). Developmental state, economic transformation and social diversification in Ethiopia (ISPI Analysis No. 163). Retrieved from https://www.ispionline.it/en/pubblicazione/developmental-state-economictransformation-and-social-diversification-ethiopia-7650

Federal Democratic Republic of Ethiopia (FDRE). (1995). The Constitution of Federal Democratic Republic of Ethiopia, Proclamation No. 1/1995.

Fesseha Mulu and Abtewold Moges. (2017). Ethiopia: a democratic developmental state? ILIRIA International Review, 7(2), 9-26.

Freedom House. (2018). Freedom in the world 2018: Ethiopia profile. Retrieved from https://freedomhouse.org/report/freedom-world/2018/ethiopia

Fritz, V., \& Menocal, A. R. (2007). Developmental states in the new millennium: Concepts and challenges for a new aid agenda. Development Policy Review, 25(5), 531-552.

Fukuyama, F. (1989). The end of History? The National Interest, 16, 3-18. 
Endalcachew Bayeh

Gebremariam, Eyob. (2018). "The carrot and stick of Ethiopian 'Democratic Developmentalism': ideological, legal and policy frameworks" In Tapscott C. et al., (Eds.), The democratic developmental state: North-south Perspectives. Stuttgart: Ibidem Verlag.

Haggard, S. (2018). Developmental States: Elements in the politics of development. United Kingdom: Cambridge University Press.

Heywood, A. (2010). Political ideologies: An introduction ( $3^{\text {rd }}$ ed.). New York: Palgrave Macmillan.

Heywood, A. (2013). Politics (4th ed.). UK: Palgrave Macmillan.

Inter-Agency Research and Analysis Network (IRIS). (2017). East Africa and the Horn in 2022: An outlook for strategic positioning in the region. France: Author.

Johnson, C. (1982). MITI and the Japanese miracle: The growth of industry policy, 1925-1975. California: Stanford University Press.

Kim, W. (2009). Rethinking colonialism and the origins of the developmental state in East Asia. Journal of Contemporary Asia, 39(3), 382-399.

Lefort, R. (2012). Free market economy, 'developmental state' and party-state hegemony in Ethiopia: the case of the 'model farmers. J. of Modern African Studies, 50(4), 681-706.

Markakis, J., \& Nega Ayele. (1986). Class and revolution in Ethiopia. New Jersey: Red Sea Press.

Matfess, H. (2015). Rwanda and Ethiopia: Developmental authoritarianism and the new politics of African strong men. African Studies Review, 58, 02, 181 204.

Melisew Dejene and Cochrane, L. (in press). Ethiopia's developmental state: A building stability framework assessment. Development Policy Review. doi: $10.1111 /$ dpr.12414

Mesgna Gebretensae. (2015). The challenges and prospects of building a developmental state in Africa: A comparative study of Botswana and Ethiopia (master's thesis). Addis Ababa University. Retrieved from: http://etd.aau.edu.et/bitstream/handle/123456789/340/mengna\%20gebrete nsae.pdf?sequence $=1 \&$ is Allowed $=y$

Michael Woldemariam. (September, 2018). Can Ethiopian's reforms succeed? what abiy's plans mean for the country and the region? Foreign Affairs Magazine, 97(5).

Retrieved from https://www.foreignaffairs.com/articles/east-africa/201809-10/can-ethiopias-reforms-succeed 
Minns, J. (2006). The Politics of Developmentalism: The Midas States of Mexico, South Korea and Taiwan. New York: Palgrave Macmillan.

Mkandawire, T. (2001). Thinking about developmental states in Africa. Cambridge Journal of Economics, 25, 289-313.

Müller, F. (2015). Model transfer in the making: Changing development strategies of, and expectations towards, the state in Ethiopia and Ghana (Working Papers Series Nr.15). Retrieved from: https://lost-research-group.org/wpcontent/uploads/2017/05/SPP1448_WP15_Mueller.pdf

Öniş, Z. (1991). The Logic of the developmental state. Comparative Politics, 24(1), 109-126.

OPHI. (2017). OPHI Country briefing 2017: Ethiopia. Oxford: Oxford University. Retrieved from:

www.dataforall.org/dashboard/ophi/index.php/mpi/download_brief_files/E $\mathrm{TH}$

Planel, S., \& Bridonneau, M. (2015). Glocal Ethiopia: Scales and power shifts. EchoGéo, 31, 1-16. doi : 10.4000/echogeo.14219

Sehen Bekele, \& Tsegaye Regassa. (2012). Democratization in a developmental state: The case of Ethiopia, issues, challenges, and prospects. Ethiopia: UNDP Ethiopia. Retrieved from:

https://www.undp.org/content/dam/ethiopia/docs/Democratization\%20in\% 20a\%20Developmental\%20State.pdf

Solomon Dersso. (2018). Ethiopia's spring of hope and winter of despair. Retrieved from http://ethiotana.com/ethiopias-spring-of-hope-and-winterof-despair/

Thakur, Monika. (2009). Building on Progress? Chinese Engagement in Ethiopia (Occasional Paper No 38). The South African Institute of International Affairs (SAIIA)

Transparency International. (2018). Corruption Perceptions Index 2018. Retrieved from https://www.transparency.org/cpi2018

Tsehai Alemayehu. (2009). The Ethiopian developmental state: Requirements and perquisites. Journal of Business \& Economics Research, 7(8), 11-18.

UNDP. (2017). Understanding African experiences in formulating and implementing plans for emergence: A Case Study of Growing Manufacturing Industry in Ethiopia. Retrieved from: https://www.et.undp.org/content/ethiopia/en/home/library/poverty/underst anding-african-experiences-in-formulating-and-implementin.html

UNDP. (2018). Quarterly Economic Brief: United Nations Development Programme Ethiopia (Volume I). Retrieved from 
http://www.et.undp.org/content/dam/ethiopia/docs/Quarterly\%20Economi c\%20brief\%201st\%20quarter\%202018.pdf

United Nations. (2007). Economic development in Africa: Reclaiming policy space: Domestic resource mobilization and developmental states. United Nations: New York and Geneva.

World Bank. (2018a). Ethiopia, GDP Growth (Annual \%). Retrieved from https://data.worldbank.org/indicator/NY.GDP.MKTP.KD.ZG?locations=E T\&year_high_desc=true

World Bank. (2018b). Ethiopia: Overview. Retrieved from https://www.worldbank.org/en/country/ethiopia/overview

World Bank. (2018c). Ethiopia: Recent developments. Retrieved from http://pubdocs.worldbank.org/en/471041492188157207/mpo-eth.pdf

Wubalem Mengistie. (2016). Money laundering and its consequences in Ethiopia (master's thesis). St. Mary's University. Retrieved from: http://etd.aau.edu.et/bitstream/handle/123456789/7264/Ashenafi\%20Lake w.pdf? sequence $=1$ \&isAllowed $=\mathrm{y}$

Yusuf Teshale. (2018). Political transition in theory and practice: Reflections on the Case of Ethiopia, (Lecture organized by Ethiopian Legal Professionals Association of Canada (ELPAC)). Retrieved from https://ethiotorontoevents.com/event/political-transition-in-theory-andpractice-reflections-on-the-case-of-ethiopia/ 